\title{
Serine/Threonine-Protein Phosphatase 2A 56 kDa Regulatory Subunit Beta Isoform
}

National Cancer Institute

\section{Source}

National Cancer Institute. Serine/Threonine-Protein Phosphatase 2A 56 kDa Regulatory

Subunit Beta Isoform. NCI Thesaurus. Code C34088.

Serine/threonine-protein phosphatase 2A $56 \mathrm{kDa}$ regulatory subunit beta isoform (497 $\mathrm{aa}, \sim 57 \mathrm{kDa}$ ) is encoded by the human PPP2R5B gene. This protein may be involved in the localization of protein phosphatase $2 \mathrm{~A}$. 